\title{
土木学会論文報告集
}

第 252 号・1976 年8 月

\section{水中における砂れきの掘削抵抗に関する実験的研究* \\ EXPERIMENTAL STUDY OF THE RESISTANCE OF EXCAVATION AGAINST SUBMERGED SANDY SOIL OR GRAVELS}

\author{
室達 朗** \\ By Tatsuro MURO
}

\section{1. まえがき}

近年，海洋土木の時代を迎え，ますます水中における 土木工事が増大してきた。.この水中における土砂の掘削 においては, 掘削速度の増大とともにその掘削抵抗は著 しく増大することや掘削刃先の摩耗が陸上工事と比較し て激しくなるなど，陸上での掘削作業とは異なった特性 を示寸ことが知られている.これは，水浸状態にある土 砂の間隙传存在する間隙水の挙動によって大きな影響を 受けるためであり，その挙動特性を解明することが水中 での掘削抵抗を知るうえで重要なかぎとなる.

従来，著者らの行った丸鋼による掘削試験において は, 砂れきの含水状態が水浸状態にあるとき, 掘削抵抗 におよぼす掘削速度の効果が最も著しいことが判明して いる1 。その原因としては，粒径の比較的大きな砂れき の場合，掘削速度が増大寸るほどせん断に伴ら土砂の急 激な体積膨張により発生する負の間偿水圧が生じ，土粒 子間の有効応力が増大することが考えられる．この場 合，発生した間隚水圧によって，間隚水が砂れきの間隚 を通過する間に失う摩擦損失水頭のために間隚水圧の絶 対值が低下寸る現象を無視するわけにはいかない，ま た，水浸砂れき中を移動する掘削棒に作用する動水圧に 対応する負の間隙水圧が掘削棒とともに移動する土塊中
に発生することが考えられ，さらに，掘削速度が増大す ると, 土砂と水とが渾然一体となった粘性抵抗として掘 削速度の平方に比例した因子が加わると推察される.

ここでは，水中における砂れきの掘削抵抗について， 主として, 実験結果に基づいて考察していくことを本研 究の目的とした.そのために，二，三の実験を行い，種 々の掘削速度に対する掘削抵抗および発生間隚水圧の大 きさを測定した．その後，掘削に伴って発生する間隚水 圧の挙動について考察し, 水中における掘削抵抗を砂れ きの諸特性と掘削速度に関していかなる関数形で表現し ていくかについて次元解析を行った．また，得られた解 析式と実験式との対応関係から，水中において掘削抵抗 を増大せしめている要因の分析を行った。 なお, 得られ た新しい知見に基づいて，水中での掘削抵抗を減少させ るための方法を提案し，いくつかの実験を行った結果に ついて記述した。

\section{2. 実験方法および装置}

\section{（1）試料砂れき}

実験に使用した 6 種類の砂れきの諸特性として，平均 粒径 $m$, 均等係数 $U_{c}$, および水浸状態における間嚐比 $e$, 湿潤密度 $\gamma_{t}$, 透水係数 $k$, 切削強度指数 $e_{s},{ }^{2)}$ 非排水

表一1 水漫状態における試料砂れきの諸特性

\begin{tabular}{|c|c|c|c|c|c|c|c|c|c|c|c|c|}
\hline 記号 & 名 & & 称 & $\begin{array}{c}\text { 半均粒径 } \\
(\mathrm{mm})\end{array}$ & $\begin{array}{c}\text { 均等係数 } \\
U_{c}\end{array}$ & $\begin{array}{c}\text { 間 隙 比 } \\
e\end{array}$ & $\begin{array}{l}\text { 密 }{ }^{\text {度 }} \\
\mathrm{rt}_{t} \\
\left(\mathrm{~g} / \mathrm{cm}^{3}\right)\end{array}$ & $\begin{array}{c}\text { 透水係数 } \\
k \\
(\mathrm{~cm} / \mathrm{sec})\end{array}$ & $\begin{array}{c}\text { レイノルズ数 } \\
R_{\theta}\end{array}$ & $\begin{array}{l}e_{s} \times 10^{-3} \\
\left(\mathrm{~kg} / \mathrm{cm}^{3}\right)\end{array}$ & $\begin{array}{c}\varphi^{\prime} \\
\text { (度) }\end{array}$ & $\begin{array}{c}\varphi \\
\text { (度) }\end{array}$ \\
\hline $\mathrm{A}$ & 標 & 準 & 砂 & 0.24 & 1.85 & 0.81 & 1.91 & $6.6 \times 10^{-3}$ & 0.07 & 11.9 & 34.5 & 34.0 \\
\hline B & 細 & & 砂 & 0.44 & 1.60 & 0.79 & 1.95 & $6.2 \times 10^{-3}$ & 0.12 & 21.7 & 37.5 & 36.8 \\
\hline C & 粗 & & 砂 & 1.00 & 4.12 & 0.88 & 1.89 & $8.9 \times 10^{-3}$ & 0.40 & 7.6 & 40.0 & 39.2 \\
\hline D & 紐 & れ & き & 5.10 & 1.64 & 1.10 & 1.82 & 1.80 & 43.0 & 10.7 & - & - \\
\hline $\mathrm{E}$ & 粗 & 机 & ह & 7.12 & 1.43 & 0.82 & 1.92 & 2.12 & 72.6 & 15.7 & - & - \\
\hline $\mathrm{F}$ & 承 & & 1i & 5.01 & 1.41 & 0.61 & 1.99 & 1.94 & 44.3 & 10.8 & - & - \\
\hline
\end{tabular}

* 本論文の一部は, 第 9 回および第 10 回土質工学研究発表会にて発表済である.

** 正会員 工博 福井大学助教授 工学部建設工学科 


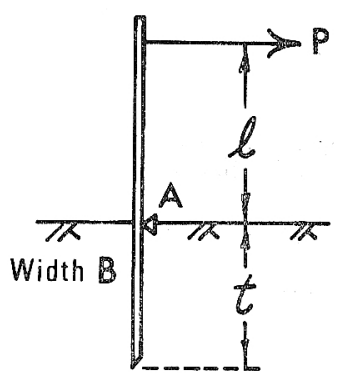

図一1切削強度試験方法

試験を行った場合の内部摩擦

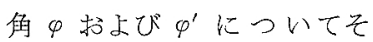
れぞれ試験した結果を 表一1 に示した.ここで, 切削强度 指数 $e_{s}$ の测定にあたっては,

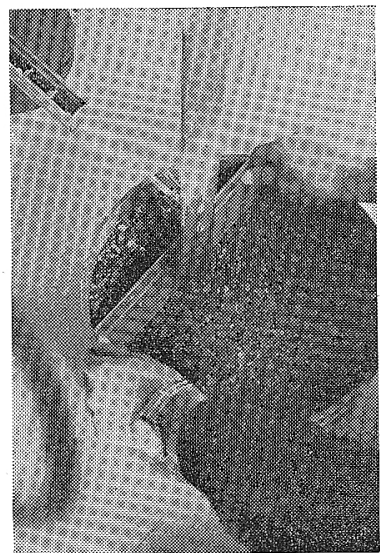

写真-1 切削強度指数 $\boldsymbol{e}_{s}$ の測定
直径 $31 \mathrm{~cm}$, 深さ $25 \mathrm{~cm}$ の円筒土槽内に試料砂れきを入 れ，図一1 および写真一1に示すように，幅 $B=5 \mathrm{~cm}$, 厚さ $6 \mathrm{~mm}$ の鋼板を深さ $t \mathrm{~cm}$ だけ砂れき中に押込み， A 点を支承として上方 $l \mathrm{~cm}$ の位置でばねばかりによ。 て最大引張力 $P$ を計測した. その後, 切削強度指数 $e_{s}$ $\left(=P l / B t^{3}\right)$ を種々の梁さ $t$ 乱よ゙高さ $l$ に刘して算定 した.

なお，透水係数 $k$ を求めるにあたっては，試料砂 $\mathrm{A}$ ， $\mathrm{B}, \mathrm{C}$ に対しては変水位透水試験, 試料机き $\mathrm{D}, \mathrm{E}, \mathrm{F}$ に 対しては定水位透水試験を行った，それぞれの試験に対 して Reynold 数 $R_{e}{ }^{3)}$ 算定した結果, 同表に示すよう に, 試料砂 $\mathrm{A}, \mathrm{B}, \mathrm{C}$ の細粒砂では層流領域で， D, E, F の粗粒れきでは乱流領域で試験を行っていることが判明 した.しかし，後述の実験においては，約 $200 \mathrm{~cm} / \mathrm{sec}$ までの高速での掘削速度を問題とするので間隙水の流れ

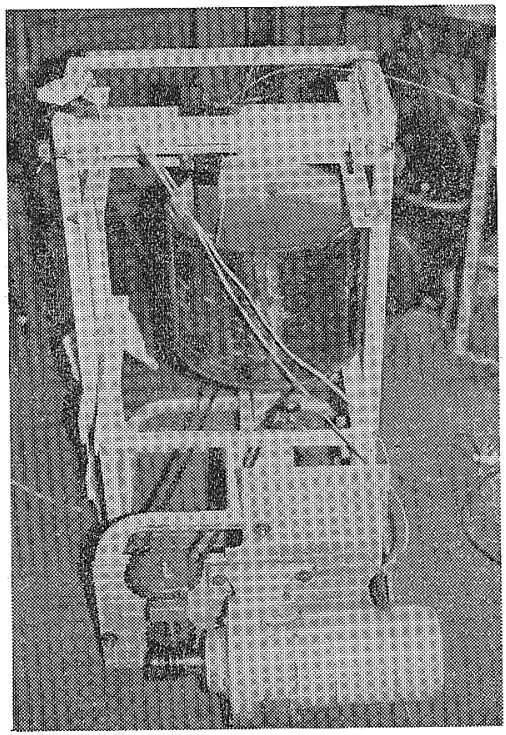

写真一2 実 験 装 置
はすべて乱流状態にあることが確認された。

\section{（2）実験装置}

写真一2 注実験装置，図一２㹥々の掘削抵抗，間 隙水生測定装置と貲流水供給装置の概略図を示す. 掘削棒は, 一辺が $3.0 \mathrm{~cm}$ の正方形断面䘮有する長 さ $30 \mathrm{~cm}$ の鋼棒であり，掘削棒前面には下端部よ り $3.0 \mathrm{~cm}$ の位置の中心線上に間幥水圧測定用扝よ び噴射水を供給するための孔（直径 $5 \mathrm{~mm}$ の円孔） が設置されている.また，図において，掘削棒の掘 削深さを $z_{0}$ で表わし，掘削に伴う砂れきの盛り上 り高さを考慮した場合の掘削深さを $z$ ，㧤よびその 盛り上り部分と掘削棒との接する位置加ら間隚水圧 測定用孔までの距離を $z^{\prime}$ とした。間隚水圧は間隚 水圧計に連結され，また，掘削抵抗は掘削棒上部に貼 り付けたペーパーダージ（電気抵抗線ひずタ計）を通し て，オシログラフに自記させるものとした．また，間隌 水圧注，掘削棒の壁面（掘削刃面）だけでなく，掘削さ れる砂れさ中の閒陌水王分布を測定するために長さ 8 $\mathrm{cm}$, 内径 $1.0 \mathrm{~mm}$ の注射針を所定の位置に鉛直に設置 して測定した.

なお，掘削棒拉よび閒隚水圧測定装置一式は固定し， 土槽を㐫る一定の速度で移動させるものとした，その移 動速度は低速域におうて, $3.88,5.82$, および $7.76 \mathrm{~cm} /$ sec の 3 段階とし, 高速域においては $70 \sim 180 \mathrm{~cm} / \mathrm{sec}$ の閒を 5 段階に変速させうる装置を製作した。また，噴 射水は，最大圧力 $5 \mathrm{~kg} / \mathrm{cm}^{2}$ まで与えることが可能であ る容量の大きいコンプレッサーを使用し，蓄圧タンクを 通して供給した．また，噴射ノズルの内径は $2 \mathrm{~mm}$ 径で あり,ノズルより噴出される水の流量は 0.5 気圧に対し

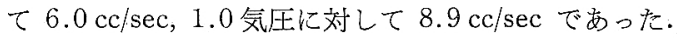

\section{（3）実験の方法}

前述した 6 種類の試料砂れさに対して水中掘削抵抗お $V_{0}=4 \sim 180 \mathrm{~cm} / \mathrm{sec}$

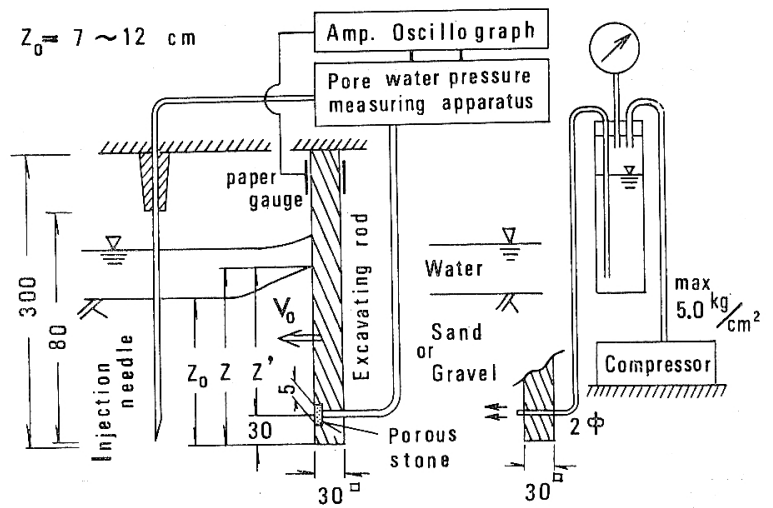

图一2 掘削装置および噴流水供給装置 
よび発生間偿水圧が掘削速度とともにどのように変化し ていくかについて実測を行った。この際, 掘削深さは 7 $\mathrm{cm} \sim 12 \mathrm{~cm}$ の間とし，掘削抵抗の 経時変化をオシログ ラフで測定した．試料砂の密度は水浸状態で一定となる ように努めた。特に, 細粒砂の場合は自重による圧縮に より時間の経過とともに高密化する傾向にあり, 注意を 要した.

また, 豊浦標準砂（試料砂 A）に対しては, 掘削にと もなら発生間鿣水圧の分布状況を調查するために注射針 を所定位置に設置し，発生間隙水圧の測定を行い，さら に, 低速域に㧍ける掘削抵抗と掘削速度との関係を求め た.

なお，実験の手順としては，それぞれの試料砂れきを 土槽内に充填し, 水面下に水浸させて掘削棒を深さ 7 $12 \mathrm{~cm}$ の間を $1 \mathrm{~cm}$ きざみに 6 段階にセットし, 土槽を 所定の速度 $(180 \mathrm{~cm} / \mathrm{sec}$ までを 10 段階に分割) で移動 させ，固定された掘削棒仁作用する掘削抵抗と掘削刃面 上の間隙水圧を測定していくのである，なお，それぞれ の試験の測定回数は測定精度を向上させるため，3 回以 上とした.

3. 水中掘削抵抗, 発生間隙水圧, および掘削 速度との関係

まず，試料砂 Aである豊浦標準砂に対する水中掘削抵 抗と発生間隙水圧分布について測定を行い，その後，水 中掘削抵抗と掘削速度の関係, および発生間隚水圧と掘 削速度との関係を求めた.

図一3 は，掘削棒のすくい角 $\alpha=0^{\circ}$, 横すくい角 $\beta=$ $0^{\circ}$ とし, 静止時における掘削深さ $z_{0}$ を $7 \mathrm{~cm}$, 掘削速 度を $5.82 \mathrm{~cm} / \mathrm{sec}$ とした場合の掘削抵抗および掘削棒の 進行方向にそって前方 $3 \mathrm{~cm}$, 染さ $4.5 \mathrm{~cm}$ の位置にお ける発生間幥水圧の経時変化をオシログラフに記録させ たものである. 図より明らかに, 掘削直後において掘削 抵抗掞よび発生間览水圧は寸るどい立上りを見せるが， その後は定常状態に達する. また, 発生間隚水圧は最初

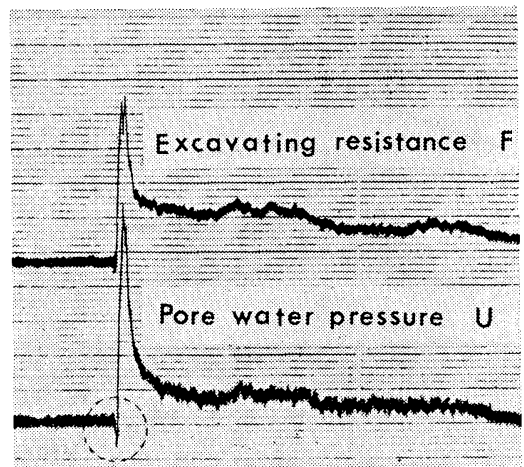

図一3 掘削抵抗と間隙水圧（負值）の測定例， 紙送り速度 $100 \mathrm{~cm} / \mathrm{min}$
わずかに正の值を示寸がダイレイタンシーによる傊圧が 大きく記録されている。同様に，図一4 は，掘削棒の進 行方向中央断面に打ける掘削直後のピーク時の発生間隚 水圧を測定し, その発生間偿水圧分布を等圧線として示 したものである．図より，す心゙り線近傍に执いては鱼の 発生間隚水圧の絶対值法減少しており，これはすべり 線上で体積膨張を引きおこしたことを実証するもので ある. 図一5 は，掘削速度を $3.88 ， 5.82$ ，および 7.76 $\mathrm{cm} / \mathrm{sec}$ とした場合の掘削初期（掘削直後のピーク時） および定常時に㧍ける掘削抵抗 $F$ と掘削速度 $v_{0}$ の関 係を示したものである.すなわち, この範囲の低速度域

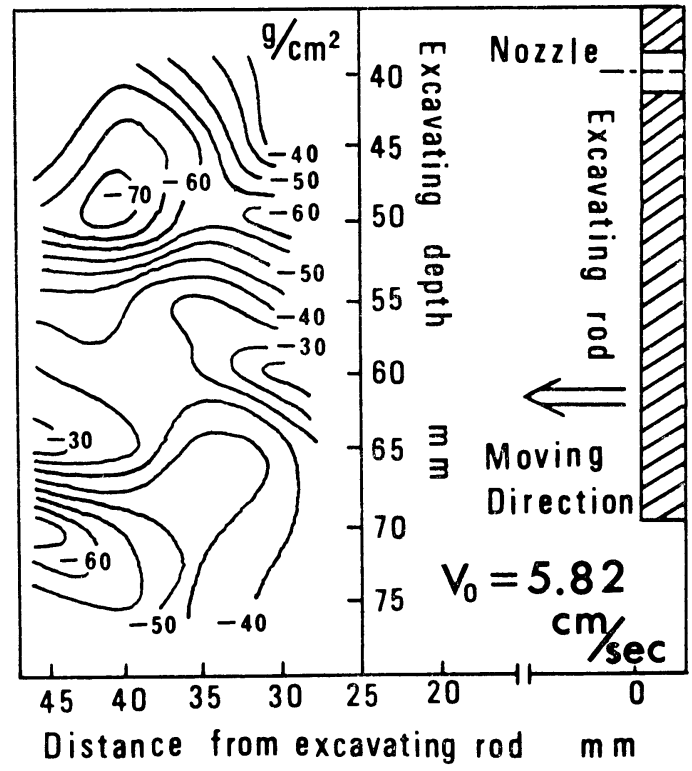

図一4掘削直後の進行方向中央断面における 発生間隙水圧分布

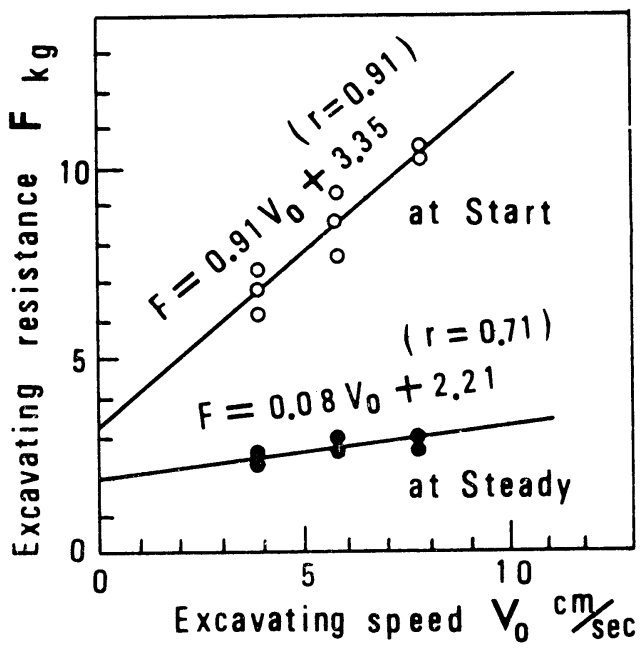

図一5 掘削初期および定常時における $\boldsymbol{F}$ と $v_{0}$ との関係 


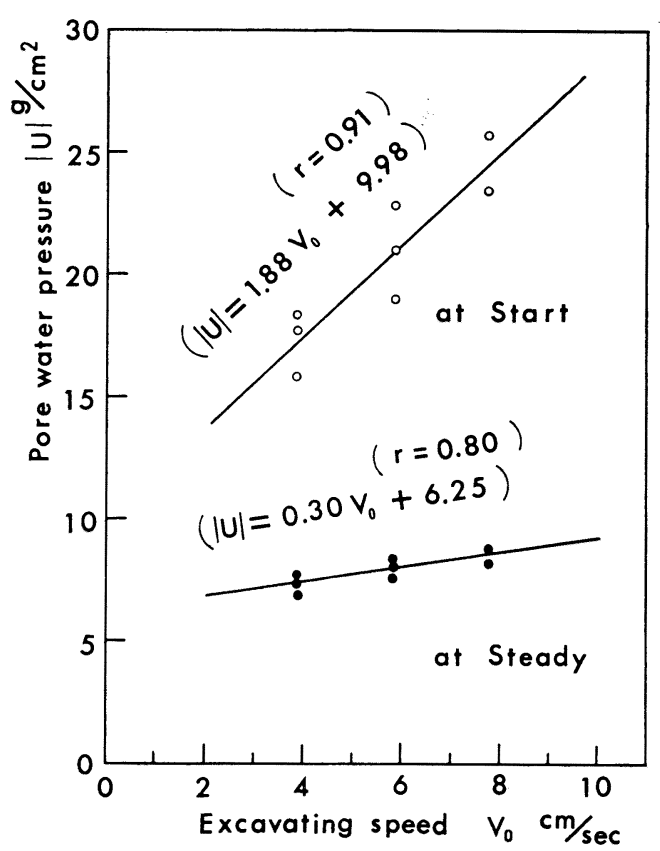

図一6＼cjkstart静止時における深さ $4.0 \mathrm{~cm}$ での掘削棒 壁面中央部に作用する発生間隙水圧（負 圧）と掘削速度との関係（豊浦標準砂）

においては, 掘削抵抗は掘削速度の増加とともに直線的 に増加していくことを意味している. また，同時に求め た負の発生間嚐水圧 $U$ の絶対值は，図一6に示したよ らに, 掘削抵抗 $F$ と同様に掘削速度に 比例して増大す ることが判明した. なお，この場合の発生間隚水圧 $U$ は掘削棒壁面中央部において静止時における試料表面か らの深さ $4.0 \mathrm{~cm}$ の位置に作用寸る間鄚水圧である（図 -1 参照). このように, 低掘削速 度域においては, 掘削抵抗および発 生間隊水圧を掘削速度の 1 次関数で 表わすと, その相関性がかなり高い ことが示され, 低速域においては, 掘削速度の 2 乗の項はほとんど存在 しないことが判明した.

次に, 試料砂 $\mathrm{A}, \mathrm{B}, \mathrm{C}$ の細粒砂 グループと試料れき $\mathrm{D}, \mathrm{E}, \mathrm{F}$ の粗 粒れきグループのそれぞれに対する 試験を行った結果をより一般的に表 現するため, 掘削抵抗 $F$ の值を掘削 刃の刃幅 $b$, 切削強度指数 $e_{s}$, およ び掘削深さ $z_{0}$ の自乗との積 $b e_{s} z_{0}{ }^{2}$ で除した值, および発生間隚水圧 $U$ の值を $\gamma_{w} z^{\prime}$ で除した值と掘削速度: 准との関係を求めることとする.

\section{（1）細粒砂に対する挙動}

試料砂 $\mathrm{A}, \mathrm{B}$ および C の 3 種類を細粒砂グループと して試験結果を整理することとする. 所定の掘削棒を掘 削深さ $z_{0}=6 \mathrm{~cm}$ から $12 \mathrm{~cm}$ までの範囲の種々の值に 設置し, すくい角 $\alpha=0^{\circ}$, 横すくい角 $\beta=0^{\circ}$ とした場合 の掘削抵抗が水中において掘削速度とともにどのように 変化するかについて試験を行った. 図一7 は, 種々の細 粒砂および掘削深さに対して, 掘削抵抗を一般的に表示 するための無次元積 $F / b e_{s} z_{0}{ }^{2}$ と掘削速度 $v_{0}$ との関倸 を掘削初期および定常時に対して図示したものである. いずれの場合にも, 無次元表示された掘削抵抗は掘削速 度の 2 次関数で表わされ, 最小自乗法によって係数の最 確值を求めると次の実験式が成立した， $v_{0}$ の単位を $\mathrm{cm} / \mathrm{sec}$ として,

掘削初期（以下, この場合の $F$ 值は起動抵抗を示す）

$$
\frac{F}{b e_{s} z_{0}^{2}}=1.20 \times 10^{-4} v_{0}^{2}+1.55 \times 10^{-2} v_{0}+4.08
$$

定常時

$$
\frac{F}{b e_{s} z_{0}^{2}}=6.50 \times 10^{-5} v_{0}^{2}+7.12 \times 10^{-3} v_{0}+1.34
$$

これらは, $F / b e_{s} z_{0}{ }^{2}$ の平均值に対して $\chi^{2}$ 分布表より 2 次曲線に対する適合度は十分高いことが判明している. 次に, 掘削抵抗を測定すると同時に掘削棒の前方壁面上 に設置した間隚水圧測定用孔を通して測定した発生間隚 水圧 $U$ を $\gamma_{w} z^{\prime}$ で除した值と掘削速度 $v_{0}$ との関係を 求めると, 図一8 および 図一9に示すように, 掘削初期 および定常時において 2 次関数で表現されることが判明

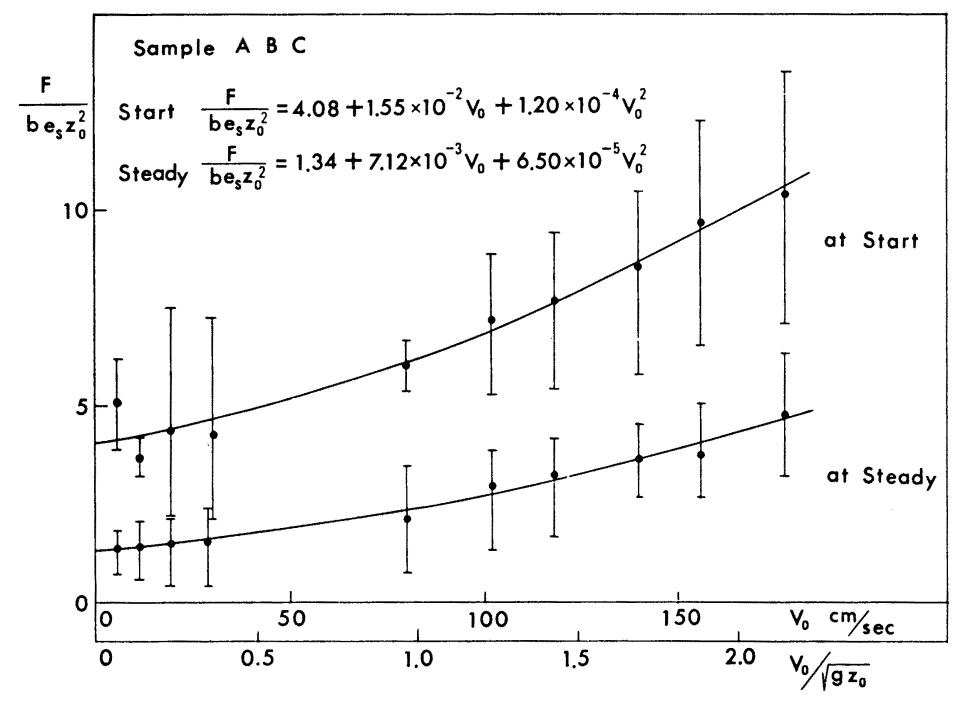

図一7F/be $\boldsymbol{F}_{s}{ }^{2}$ と掘削速度 $v_{0}$ (フルード数 $v_{0} / \sqrt{\boldsymbol{g} \boldsymbol{z}_{0}}$ ) との関係, 試料砂 $\mathbf{A B C}$ 


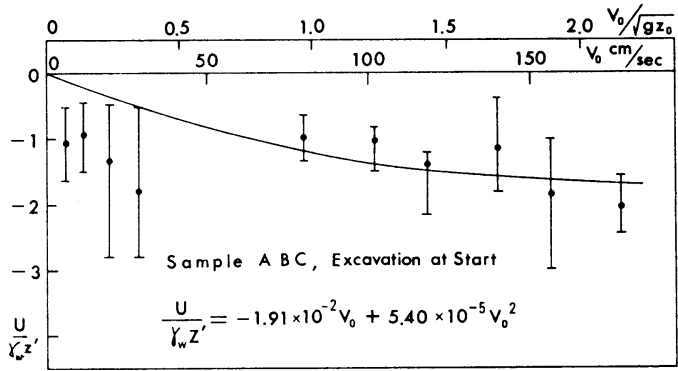

図-8 $U / \gamma_{w} z^{\prime}$ と掘削速度 $v_{0}\left(\right.$ フルード数 $v_{0} / \sqrt{g z_{0}}$ ) との関係（掘㴥初期, 試料砂 $\mathrm{ABC}$ )

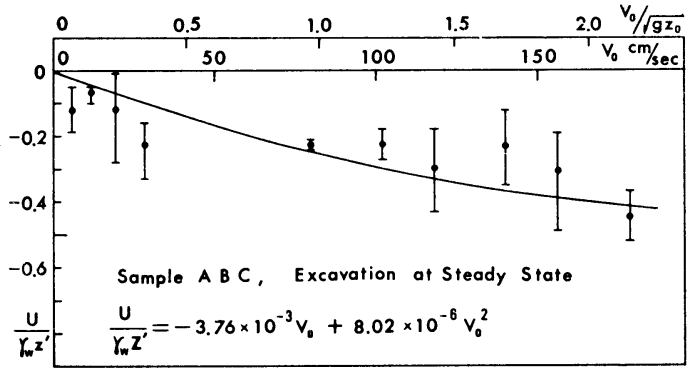

図一9 $U / \gamma_{w} z^{\prime}$ と掘削速度 $v_{0}\left(\right.$ フルード数 $\left.v_{0} / \sqrt{g z_{0}}\right)$ との関係 (定常時, 試料砂 $\mathrm{ABC}$ )

した．すなわち，実験式として次式が成立した。 掘削初期

$$
\frac{U}{r_{w} z^{\prime}}=-1.91 \times 10^{-2} v_{0}+5.40 \times 10^{-5} v_{0}^{2} \cdots
$$

定常時

$$
\frac{U}{r_{w} z^{\prime}}=-3.76 \times 10^{-3} v_{0}+8.02 \times 10^{-6} v_{0}^{2} \cdots
$$

なお，上式において， $v_{0}$ の単位は $\mathrm{cm} / \mathrm{sec}$ である. ま

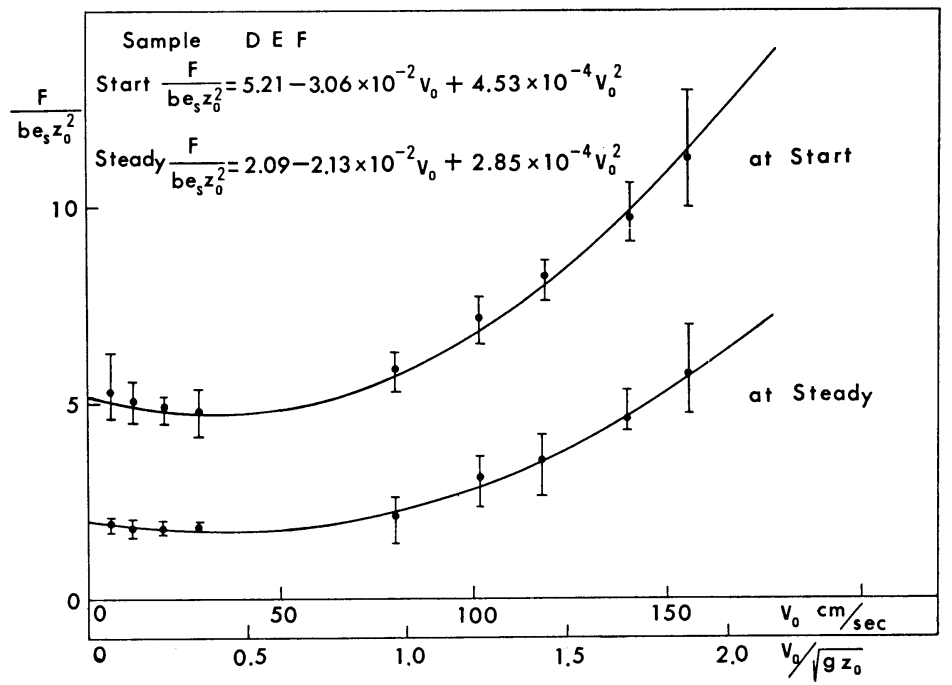

図一10 $\frac{F}{\mathrm{be}_{s} z_{0}{ }^{2}}$ と掘削速度 $v_{0}$ (フルード数 $\left.v_{0} / \sqrt{\boldsymbol{g z}_{0}}\right)$ との関係, 試料れき DEF

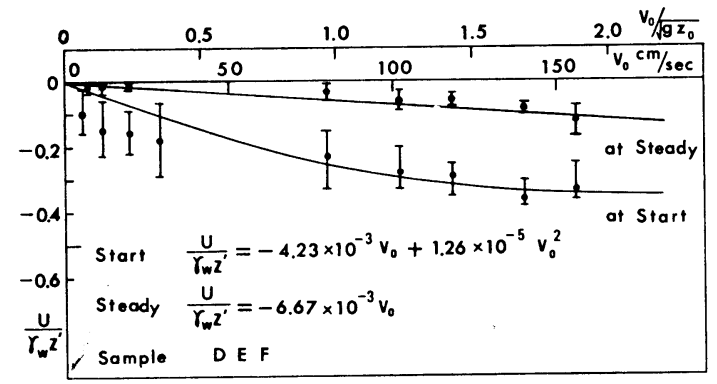

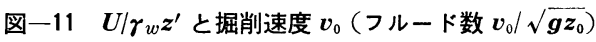
との関係, 試料れき DEF

た, $v_{0}=0$ において, 試料砂は排水状態にあり, 過剩間 隙水圧は発生しないことを前提としたものであるが，低 速域においては，図より明らかに，わずかに間隙水圧の 絶対值は大きくでる傾向にあった。

\section{（2）粗粒れきに対する挙動}

ここでは, 粒径の大きい試料れき $\mathrm{D}, \mathrm{E}, \mathrm{F}$ の 3 種類 を粗粒れきグループとして整理することとする．前節で 行ったと同様化，掘削樑さ $z_{0}$ を $6 \mathrm{~cm}$ から $12 \mathrm{~cm}$ ま での間で掘削棒を設置し，また，掘削抵抗および間隙水 圧は同様な方法で測定した. 図一10 は，掘削抵抗と掘 削速度との関倸を掘削初期および定常時に対して求めた ものである. その結果, 掘削抵抗は掘削速度の 2 次関数 として次式に示す実験式がえられた.

掘削初期

$$
\frac{F}{b e_{s} z_{0}^{2}}=5.21-3.06 \times 10^{-2} v_{0}+4.53 \times 10^{-4} v_{0}^{2}
$$

定常時

$$
\begin{aligned}
\frac{F}{b e_{s} z_{0}{ }^{2}}= & 2.09-2.13 \times 10^{-2} v_{0} \\
& +2.85 \times 10^{-4} v_{0}^{2}
\end{aligned}
$$

なお，上式において， $v_{0}$ の単位は $\mathrm{cm} / \mathrm{sec}$ である. また，同時に測定し た間隙水圧より算定した $U / r_{w} z^{\prime}$ の掘 削速度にともなら変化は, 図一11に 示すように, 2 次曲線として次の実験 式が成立した。

掘削初期

$$
\begin{aligned}
\frac{U}{r_{w} z^{\prime}}= & -4.23 \times 10^{-3} v_{0} \\
& +1.26 \times 10^{-5} v_{0}^{2} \cdots(7)
\end{aligned}
$$

定常時

$$
\frac{U}{r_{w} z^{\prime}}=-6.67 \times 10^{-3} v_{0}
$$

なお, 上式において $v_{0}$ の単位は 
$\mathrm{cm} / \mathrm{sec}$ である. また，式（8）においては速度の自乗の 項恃無視することができる.

\section{4. 水中掘削抵抗に関する考察}

砂質土の水中掘削においては負の発生間隚水圧が発生 し，その絶対值は掘削速度 $v_{0}$ の増加とともに増大して いく傾向にあることは前述の実験の結果より確認されて いる. この掘削棒の移動に伴って発生する間隚水圧を分 析すると，砂粒子の急激なせん断にともなって発生する ダイレイタンシーによる負の過剰間隚水圧 $p$ とその消 散過程, および水浸砂れきの流体中において掘削棒の運 動によって発生する流体抵抗である動水圧の変化として とらえられる砂れき中の負の間隚水圧 $\Delta q$ とその消散過 程に大別される.

まず，砂粒子のせん断にともなうダイレイタンシーに よって発生する過剩間嚐水圧 $p$ は, 非排水状態におい て八面体垂直応力 $\sigma_{\mathrm{oct}}$ と八面体せん断応力 $\tau_{\mathrm{oct}}$ の関数 として次式で与えられることは周知の事実である.

$$
p=\frac{1}{1+C_{v} n / 3 C_{s}}\left[\sigma_{\mathrm{oct}}+\frac{D}{3 C_{s}} \tau_{\mathrm{oct}}\right]
$$

ここに， $C_{v}$ は間潆流体の圧縮係数， $C_{s}$ は土粒子実質 部分の圧縮係数であり, $n$ は間幥率, $D$ はダイレイタン シー係数である ${ }^{4)}$.

このように, ある飽和した土要素 $\Delta V$ が急激なせん断 変形を受ける瞬間では非排水条件が保たれるが，時間の 経過とともに体積は変化し間隚水圧は消散する.この負 の過剰間隚水圧 $p$ の消散過程は, 介在する砂れきの透 水係数の大きさに左右される. たとえば, 与えられた掘 削速度 $v_{0}$ に対して透水係数 $k$ が小さい場合には動水勾 配が上昇し, 掘削速度が増大するほど絶対值の高い過剩 間隚水圧が残留することとなる．掘削に伴って発生する 負の間隚水圧 $p$ の消散過程を理論的に正確に追跡する のはかなりの困難が予想される. そのため, Lindquist の球群中を通過する間隚水の挙動に関する実験結果を適 用することとする.

Lindquist は, 直径 $d$ の球群中を通過する平均間隚 水流を $v_{m}$ として, 動水勾配 $I=\zeta v_{m}{ }^{2} / 2 g d$ ( $\zeta$ は抵抗 係数, $g$ は重力の加速度) とおいて, $R_{e} \zeta$ と $R_{e}$ の関 係を求めた結果， $R_{e}<4$ においては $R_{e} \zeta$ は一定とな り, 流れは層流で Darcy の法則が成り立つが, $R_{e}>4$ では

$$
R_{e} \zeta=a+b R_{e} \quad R_{e}=\frac{\rho v_{m} d}{\mu}
$$

が成り立つことを実証しだ5. ここに， $R_{e}$ はレイノル ズ数, $\rho$ は液体の密度, $\mu$ は液体の粘性係数, $d$ は砂れ きの平均粒径, $a$ および $b$ は定数である.
液体の動粘性倸数を $\nu(=\mu / \rho)$ として上式をかきなお すと，

$$
\begin{aligned}
I & =\frac{v_{m}{ }^{2}}{2 g d}\left(\frac{a}{R_{e}}+b\right)=\frac{a v_{m}{ }^{2}}{2 g d} \cdot \frac{\mu}{\rho v_{m} d}+\frac{b v_{m}{ }^{2}}{2 g d} \\
& =\frac{a \nu}{2 g d^{2}} v_{m}+\frac{b}{2 g d} v_{m}{ }^{2} \ldots \ldots \ldots \ldots \ldots \ldots \ldots(11)
\end{aligned}
$$

となる。

すなわち, 間隚水の流れが乱流であるとき, 単位長さ あたりの摩擦損失水頭は見かけの流速 $v_{m}$ の 2 次式で与 えられるのである.

また, 内田 ${ }^{6)}$ は多孔質の媒体を通過するレイノルズ数 の高い非線形透水解析 の結果, $R_{e}<1000$ における乱 流状態での透水係数 $k_{t}$ は, 層流状態での透水係数 $k_{l}$ を用いて次式で与えられることを Lindquist の実験式 より誘導している.

$$
k_{t}=k_{l} /\left\{1-A+A \sqrt{1+\left(R_{e} / R_{t}\right)^{2}}\right\}
$$

ここに, $A=0.20, R_{t}$ は限界レイノルズ数である.この 乱流状態に打ける透水係数 $k_{t}$ を用いて, 間幥水の平均 流速 $v_{m}$ と動水勾配 $I$ の間には次式で示寸線形関係が 成立することが運動方程式から導かれる。

$$
v_{m}=k_{t} I \cdots
$$

したがって, 掘削による砂れきのせん断によって発生す る負の間隚水圧 $p$ は, 掘削棒前面のすべり面上におい て発生し, 時間の経過とともに鉛直上方へ消散していき その動水勾配 $I$ は地表面までの鉛直距離を $z$ として, $-p_{z} / r_{w} z$ に比例すると仮定する.ここに, $-p_{z}$ は, 深 さ $z$ における発生間隚水圧であり, $\gamma_{w}$ は水の単位体積 重量である.したがって, 式（13）を変形すると次式を える.

$$
p_{z}=-c_{1} \gamma_{w} z \frac{v_{m}}{k_{t}} \quad\left(c_{1}: \text { 定数 }\right)
$$

一方, 掘削棒の移動に伴って掘削された砂れきは掘削 棒とともにある速度で静水中を移動することとなるが, このとき, 砂れきを含む混合水と掘削棒との間には流体 抵抗が作用する. この值は, 慣性抵抗として掘削速度の 自乗に坑力係数 $c_{D}$ を乗じたものと, 間隚水圧の変化に よる抵抗とに分析される.この間鄚水圧の大きさは土粒 子の移動速度から算定される間隌水の見かけの流速 $v_{m}$ の自乗に比例するものであることが, Bernoulli のエネ ルギー方程式から導かれる.

すなわち, 同一流線上の圧力水頭, 速度水頭, および 位置水頭の 和である 全水頭はつねに一定であることよ り, 位置水頭が変らない場合には, 摩擦損失水頭を考え た場合にも掘削によって発生する速度水頭の変化は圧力 水頭の変化として表われ，一般に次式によって表現され る.

$$
\frac{v_{m}^{2}}{2 g}+z+\frac{q}{r_{w}}=\text { const. }
$$


ここに，q は所定の流線上における圧力である.したが って, この場合, 掘削速度 ?。をえた場合のある位置 における間隚水の流速が 0 から $v_{m}^{\prime}$ まで変化するとし たとき発生する間隚水圧 $\Delta q$ は，一定の深さ $z$ に対し て次式で与えられる.

$$
\Delta q=-c_{2} \frac{\gamma_{w} v_{m}^{2}}{g}\left(c_{2}: \text { 定数 }\right)
$$

ここに, $\Delta q$ は負の間隙水圧, $v_{m}{ }^{2} / 2 g$ は速度水頭, ま た， $c_{2}$ は発生した 間隚水圧によって間隙水が土粒子間 偿を通過する際の摩擦損失水頭としてエネルギーを消費 するために消散していく現象を考慮した場合の係数であ り, この場合, 掘削深さの方向に対しては不変である. な㧍，掘削刃面が流線と直交する場合には，刃面上に動 水圧として正の間隚水圧が作用する.

さて, 水中掘削に扔いて発生する間鄚水圧は, 前述し たように，砂れきのせん断によって発生する間隙水圧 $p_{z}$ と, 砂れきを含む静水中の掘削棒の移動によって発 生する間隙水圧 $\Delta q$ から構成されていると仮定する. た, 両者とも, ある場所の間鿣水の平均流速 $v_{m}$ は掘削 棒の移動速度 $v_{0}$ に比例するものと仮定すると, 掘削棒 の前方壁面に作用する発生間帨水圧 $U$ は, 掘削深さ $z$ の関数として与えられる間隚水圧 $p_{z}$ と, 深さ $z$ に無 関係な間隚水圧 $\Delta q$ の和として次式で与えられると仮定 しておく.

$$
U=p_{z}+\Delta q=-\left(c_{1} r_{w} z \frac{v_{0}}{k_{t}}+c_{2} \frac{r_{w} v_{0}{ }^{2}}{g}\right) \cdots
$$

また，間隙水圧 $U$ を無次元表示するため，その間隙水 頭を深さ $z$ で除した值として表現すると，上式は

$$
\frac{U}{\gamma_{w} z}=-\left(c_{1} \frac{v_{0}}{k_{t}}+c_{2} \frac{v_{0}^{2}}{g z}\right)
$$

となる. ここで, $k_{t}$ はすでに 表一1 で与えた透水係数 $k$ に対応するものである.

なお，この関係式はすでにえられた実験式 (3)，(4) お よび (7)，(8) とよく対応するものであり，上述の考察 がある程度実証されたものと判断する.また, 定数 $c_{1}$, $c_{2}$ は，それぞれの実験式に対応させて算定した結果を 表一2 汇示した.

したがって, 掘削に伴って発生する負の間隚水圧 $U$ によって土粒子間に作用する有効応力は増大するので, 砂九きの非排水強度は増加し, 掘削抵抗は増大寸ると考 えられる. 掘削棒に抵抗する砂れき中の応力を, 一般的 に，有効応力表示抢よび全応力表示によって表現する と, 図一12 に示寸ようになる. 実線は有効応力表示, 点線は全応力表示したものである. すなわち, 静的掘削 時に扔いては, 最小主応力抢よび最大主応力を有効応力 で表わすと，掘削刃面近傍において $\gamma^{\prime} z$ および $K \gamma^{\prime} z$ $\left(r^{\prime}=r-1\right)$ となり, 一方, 掘削速度 $v_{0}$ が上昇するとと も活動的掘削となり,その最小主応力は $r^{\prime} z-p_{z}-\Delta q$ と

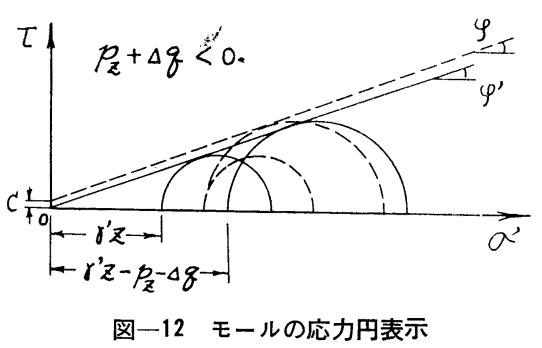

変化する．ここに， $K$ は受働土圧係数である.

$p_{z}+\Delta q$ が負の值をとれば，同じ掘削哚さに対してそ の非排水強度は増大すると考えられる. この場合の砂れ きの内部摩擦角を $\varphi^{\prime}$ とする. 次に, 以上の関係を全态 力に対して表示しなおすと, 点線で示すように左の方向 ヘモールの応力円は移動し, 一般に, 内部摩擦角 $\varphi$ は $\varphi^{\prime}$ よりわずかに大きく，見かけの粘着力が発生するた めに, 全応力で表現される 掘削抵抗は 増大するのであ る.

すでに，実験式（1），(2) および（5)，(6) で示された ように, 水中に㧍ける砂れきの掘削抵抗 $F$ は, 掘削速 度 $v_{0}$ の 2 次関数で表現されることが判明した.このよ らに, 掘削速度の増大とともに掘削抵抗が増大寸るの は，前文で述べた負の間幥水圧による有効応力の増大と 慣性によるものとに大別して考えていくこととする.さ て，慣性によるものについては，K．Wieghardt ${ }^{7}$ も指 摘しているように，乾燥砂に扔いてさえも慣性力の影響 を無視することはできない，実際，彼の実験において は, Froude 数が 1.0 までの低速域においては, 粒子 間の動摩擦係数が静的摩擦係数よりごくわずか小さいに もかかわらず，大きな面積をもつすべり面のために掘削 抵抗減少すること, および速度増加に伴って Froude 数が増加すると慣性力の影響が顕著に表われてくるため に, 乾燥砂の掘削抵抗は速度の 2 次関数で表わされるこ とが判明している．なお，本実験での水中における掘削 の場合にも，前 図一10 で示したように，粗粒れきグル 一プにおいては，低速域において掘削抵抗は減少してい るが,これは粒子間の動摩擦と静摩擦抵抗の差によると 考えられる.さらに，掘削速度の增大とともに掘削抵抗 が増大寸るのは, 有効応力の増加に伴ら摩擦抵抗の増大

\begin{tabular}{|c|c|c|c|c|c|}
\hline 定 数 & $a_{0}$ & $a_{1}$ & $a_{2}$ & $c_{1}$ & $c_{2}$ \\
\hline \multicolumn{6}{|c|}{ 細 粒 砂 グループ } \\
\hline 掘削初期 & 4.08 & $1.55 \times 10^{-2}$ & $1.20 \times 10^{-4}$ & $1.38 \times 10^{-4}$ & $-3.70 \times 10^{-1}$ \\
\hline 定常 時 & 1.34 & $7.12 \times 10^{-3}$ & $6.50 \times 10^{-5}$ & $2.70 \times 10^{-5}$ & $-5.49 \times 10^{-2}$ \\
\hline \multicolumn{6}{|c|}{ 粗 粒 れきグループ } \\
\hline 掘削初期 & $\begin{array}{l}5.21 \\
2.09\end{array}$ & $\begin{array}{l}-3.06 \times 10^{-2} \\
-2.13 \times 10^{-2}\end{array}$ & $\begin{array}{l}4.53 \times 10^{-4} \\
2.85 \times 10^{-4}\end{array}$ & $\mid \begin{array}{r}8.27 \times 10^{-3} \\
-3.10 \times 10^{-5}\end{array}$ & $\mid \begin{array}{r}-8.92 \times 10^{-2} \\
3.43 \times 10^{-2}\end{array}$ \\
\hline of if & & & & & \\
\hline
\end{tabular}
に帰因するものと考えられる.

\section{表一2 各試料砂れきに対する諸定数の算定値}


得られた実験式を一般化して表示すると，

$$
\frac{F}{b e_{s} z_{0}^{2}}=a_{0}+a_{1} v_{0}+a_{2} v_{0}^{2}
$$

となる. 定数 $a_{0}, a_{1}$ および $a_{2}$ はそれぞれの実験式に 対応させて 表一2 にまとめて示した.

\section{5. 噴流水による掘削抵抗の低減}

これまでの実験および理論的考察より明らかなように 水中掘削においては負の発生間隚水圧によって掘削抵抗 が増大することが判明した．特に，細粒砂の掘削初期に おいては掘削速度の増大とともに, この発生間仯水圧に よる掘削抵抗の増加分はかなり大きな影響を示してい る.この現象を工学的に把えるとき, 掘削刃に作用する 掘削抵抗が増大するばかりでなく，土粒子間の有効応力 が増大するために掘削刃の刃先打よび刃面が陸上工事と 比較して一段と激しく摩耗することなど大きな弊害を与 えている.

掘削抵抗を減少させるためには, 掘削に伴って発生す る負の間隚水圧の絶対值を小さくすることが根本的に重 要な問題であり，たとえば，掘削棒の先端部より高圧の 噴流水を与えることにより間隚水圧を正の方向に変化さ せる方法や高圧の圧縮空気を噴射させた場合の負の間隙 圧の絶対值の低下と空気容積の浮力による気泡の浮上に 伴ら砂粒子間嚐の増加とせん断強度の低下を目的とする 方法がある。しかし，圧縮空気による掘削抵抗の減少効 果は少ないことが実験の結果 ${ }^{8)}$ より明らかである.すな わち, これは, 空気と水との不連続性のために, 土粒子 間隚への透気効果は少なく大きな気泡となって浮上する ため, 掘削抵抗が波状的に変動するためである.ここで は，高圧の噴流水による方法に対して二，三の実験を行 い，掘削抵抗の低下に及ぼす効果について検証を行う.

実験条件は，豊浦標準砂（試料砂 A) を使用し, 初期 掘削深さ $z_{0}=7 \mathrm{~cm}$, すくい角 $\alpha=0^{\circ}$, 横すくい角 $\beta=0^{\circ}$ とし, 掘削速度 $5.82 \mathrm{~cm} / \mathrm{sec}$ で行った場合の例を以下 に示す.

さて, 掘削棒の下端より上方 $3 \mathrm{~cm}$ の中央部に直径 2 $\mathrm{mm}$ の噴砂孔をとりつけ，一定の圧力で水を噴射させた 場合の掘削抵抗の変化および発生間幥水圧に与える影響 効果について実測を行った。図一13 は，送水量を 6.0 $\mathrm{cc} / \mathrm{sec}$ とし， $0.5 \mathrm{~kg} / \mathrm{cm}^{2}$ の圧力水を噴射させた場合の 掘削抵抗と掘削棒の進行方向にそって前方 $3 \mathrm{~cm}$, 哚さ $4.5 \mathrm{~cm}$ の位置で注射針によって測定した発生間隙水圧 の経時変化をオシログラフに記録させたものである.こ れは，噴流水を与えない場合に，同じ実験条件および同 じ位置において測定した前 図一3 と比較すると，掘削 抵抗および間隚水圧はともに立ち上がりがかなり鈍くな
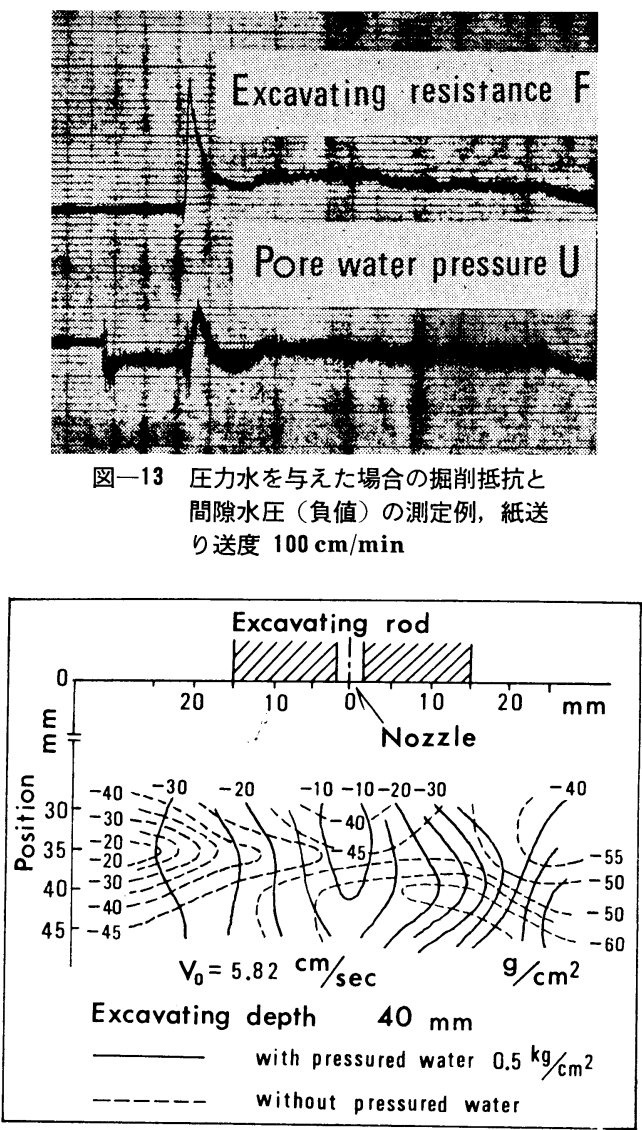

図一14 圧力水の有無に伴う発生間隙水圧分布 の変動（掘削初期）

っており，噴流水によって相当の影響を受けていると判 定される．また，図一14 は，測定結果の一例として掘 削直後のピーク時における深さ $4 \mathrm{~cm}$ (噴射孔の設置さ れた位置) の水平面上における発生間隚水圧分布を示し たものである. 実線は噴流水を与えた場合の間隚水圧分 布を，破線は噴流水を与えない場合の間隚水圧分布を等

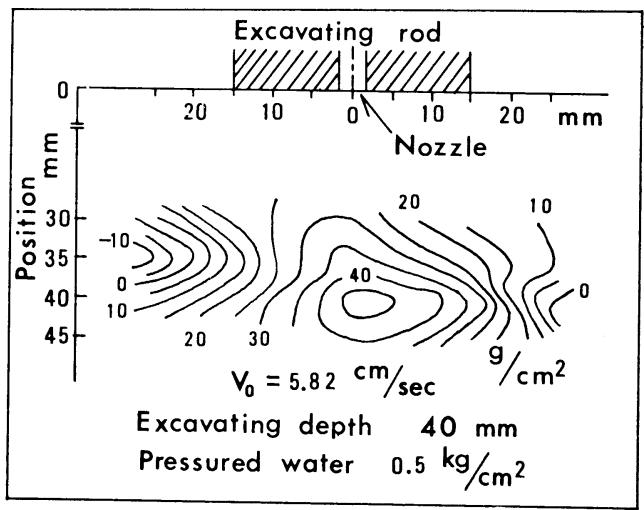

図一15掘削初期における圧力水による 増加水圧分布 


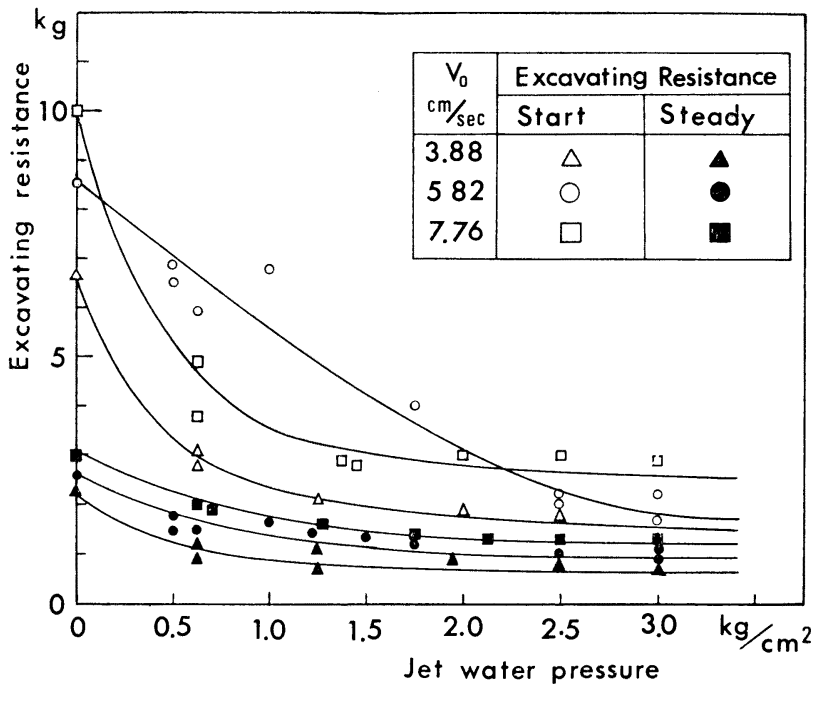

図一16 噴流水圧の增加に伴う掘削抵抗の減少

圧曲線として示した. 図より, 間隚水圧分布の変化と流 線方向の変化が明膫に示されており，噴射ノズルからの 噴流水が効果的に拡散していくことが判明した. 図一15 は, 前 図一14 より算定した発生間嚐水圧の増加分の分 布状況を示したものであり，掘削に伴って発生する負の 間隚水圧の絶対值が広範囲にわたって減少しており，間 隚水圧は正の方向へ変動していることが明らかである. これによって，掘削抵抗はかなり減少するものと期待さ れる.

さて, 噴流水の圧力をさらに増加させると掘削抵抗の 減少効果は進展していくと考えられる. 図一16 は, 掘 削速度を $v_{0}=3.88,5.82$ および $7.76 \mathrm{~cm} / \mathrm{sec}$ とした場 合の掘削抵抗と噴流水の圧力との関係を示したものであ る.

図中, 白印は掘削初期の場合, 黒印は定常時における 掘削抵抗を示したものである. 図より明らかに，特に掘 削初期における掘削抵抗は, 噴射圧力の増加とともに著 しく減少していくことが判明した.これは，別に行った 圧縮空気を噴射させて行った減少効果に比べて, 噴流水 を与えることはかなり効果があることを実証するもので あり，噴射水圧の上昇とともに最大掘削抵抗および定常 時の掘削抵抗を著しく低下させるものである.

\section{6. 結 論}

以上, 細粒砂および粗粒れきに対する水中掘削抵抗が 掘削速度の 2 次関数で表現されることを実験的に明らか にした. また，水中にあるための掘削抵抗の増分を減少 させるための噴流水の効果についても検討した. 以下 に, 得られた結果を要約する.
（1）水中における砂れきの掘削抵抗および 発生間隚水圧は, 一般に, 掘削直後にふいて鋭 い立ち上がりを見せるが，その後は一定值にま で低下する，また，掘削刃面上に作用する発生 間隙水圧は最初わずかに正の值を示すが，その 後は砂れき粒子のダイレイタンシーによる負圧 が大きく記録された.

（2）掘削に伴って発生する砂れき中の発生 間隚水圧分布は掘削直後において全般的に負圧 を示す．また，掘削によるすべり面と予想され る領域では, 負圧の絶対值は減少しており,こ れはダイレイタンシーによる体積膨張を引きお こしたことを実証するものである.

（3）細粒砂において，掘削速度が約 10 $\mathrm{cm} / \mathrm{sec}$ 以下の低速域においては, 掘削抵抗お よび負の発生間隚水圧の絶対值はともに掘削速 度に比例して増加することが判明した。

（4）実験に供した試料砂れきについて，掘削抵抗 $F$ を掘削刃の刃幅 $b$, 切削強度指数 $e_{s}$, および掘削深さ $z_{0}$ の自乗の積で除した無次元積 $F / b e_{s} z_{0}{ }^{2}$ が掘削速度の 2 次式で与えられることが，広範囲にわたる掘削速度域に 対して明確にされた.

なお, 掘削速度の自乗の項は低速域においてはきわめ て小さく,フルード数が 1.0 をこえると次第に 掘削抵 抗に影響を及ぼしている.

（5）掘削刃面に作用する負の発生間隚水圧水頭をそ の測定深さで除した值は，掘削速度の 2 次式で与えられ ることが，実験の結果判明した。これは，砂れきのせん 断に伴ら負の発生間隚水圧の消散過程における間嚐水流 の運動方程式および流体中の掘削刃の移動にともなう動 水圧の変化に対するエネルギー方程式によって構成され ると仮定すると, よくその現象を説明することができ る.

（6）水中における砂れきの掘削抵抗を支配する要因 分析の結果, 掘削抵抗は掘削刃の刃幅, 切削強度指数お よび掘削深さの自乗の積と, 透水係数, 重力の加速度お よび掘削深さの項を含む掘削速度の 2 次式との積に比例 することが推察される.

（7）細粒砂に対する実験の結果, 掘削直後のピーク 時においては, 定常時と比較して, 負の発生間隚水圧に よる掘削抵抗の増分が顕著に発生することが明らかとな った. 一方, 粗粒れきに対しては, れきの透水係数がか なり大きいために, 負の発生閒隚水圧は細粒砂ほど増大 せず, 水中掘削の特徴はそれほど表われていないことが 判明した。しかし，慣性による影響については，細粒砂 と比べて粗粒れきの方が高いことが認められた.

（8）細粒砂に対して水中掘削抵抗を減少させるた 
め, 負の発生間隚水圧の絶対值を減少させ, 正の方向一 変化させることを目的として, 掘削刃の先端部より高圧 水を噴射させるとかなり効果があることが実証された。

謝辞 : 本研究を実施するにあたり終治ご指導をい ただいた京都大学工学部教授 畠 昭治郎先生に厚く御 礼申し上げるとともに, 実験に際し多大の援助を受けた 福井大学工学部入江研究室の諸氏に謝意を表します.

\section{参 考 文 献}

1）畠 昭治郎・室 達朗：金属の摩耗に及ぼす砂れき特性と 水の影響について, 土木学会論文報告集, 第 206 号, pp. 95-110, 1972 年 10 月.

2）村山朔郎・畠 昭治郎: 土の切削強度の新測定法, 材料試 験, 4,24, pp. 381-387, 昭和 30 年 7 月.
3）久保田敬一: 浸透水と土の安定, 山海堂, pp. 40-42, 昭和 41 年.

4) Scott, R.F. : Principles of Soil Mechanics, AddisonWesley, 1963, pp. 271-272.

5) Lindquist, E. : On the Flow of Water through Porous Soil, Rep 1st Cong. Large Dams, Stockholm, 81, 1933.

6) Uchida, S. : On the Non-linear Percolation at High Reynolds' Number, Proc. 1st Japan NCTAM, 437, 1951.

7) Wieghardt,K. : Experiments in Granular Flow, Annual Review Fluid Mechanics. (A) Vol. 7, 1975, pp. 89-114.

8）室 達朗：水中における掘削抵抗の減少法について, 第 10 回土質工学研究発表会講演集, pp. 937-940, 昭和 50 年 6 月.

(1975.12.12 - 受付) 